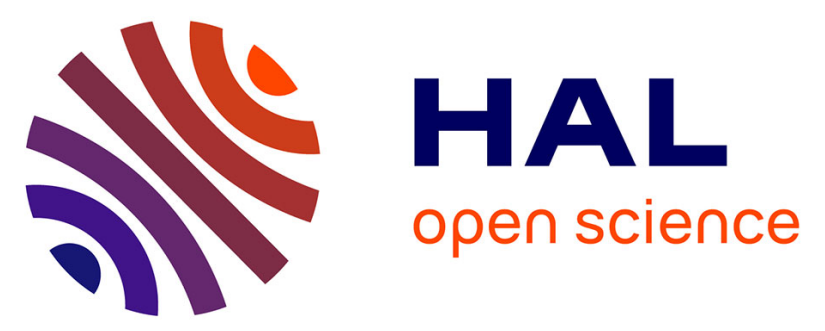

\title{
Groundwater Vulnerability and Risk Mapping Based on Residence Time Distributions: Spatial Analysis for the Estimation of Lumped Parameters
}

Myriam Dedewanou, Stéphane Binet, Jean-Louis Rouet, Yves Coquet, Ary Bruand, Hervé Noel

\section{To cite this version:}

Myriam Dedewanou, Stéphane Binet, Jean-Louis Rouet, Yves Coquet, Ary Bruand, et al.. Groundwater Vulnerability and Risk Mapping Based on Residence Time Distributions: Spatial Analysis for the Estimation of Lumped Parameters. Water Resources Management, 2015, 29 (15), pp.5489-5504. 10.1007/s11269-015-1130-8 . insu-01237105

\section{HAL Id: insu-01237105 \\ https://hal-insu.archives-ouvertes.fr/insu-01237105}

Submitted on 20 Jan 2016

HAL is a multi-disciplinary open access archive for the deposit and dissemination of scientific research documents, whether they are published or not. The documents may come from teaching and research institutions in France or abroad, or from public or private research centers.
L'archive ouverte pluridisciplinaire HAL, est destinée au dépôt et à la diffusion de documents scientifiques de niveau recherche, publiés ou non, émanant des établissements d'enseignement et de recherche français ou étrangers, des laboratoires publics ou privés.

\section{(ㅇ)(1) $\$$}

Distributed under a Creative Commons Attribution - NonCommercial - NoDerivatives 44.0 


\title{
1 Groundwater vulnerability and risk
}

2 mapping based on Residence Time Distributions: Spatial analysis for the estimation of lumped parameters

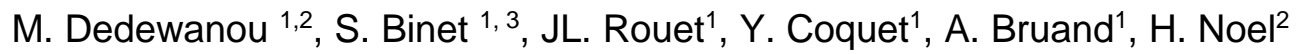 \\ ${ }^{1}$ ISTO, UMR 7327 CNRS-Université d'Orléans-BRGM, 45071 Orléans cedex 2 \\ ${ }^{2}$ GEO-HYD, 101 rue Jacques Charles, 45160, Olivet, France. \\ ${ }^{3}$ ECOLAB, UMR 5245 CNRS-UPS-INPT, 31326 Castanet-Tolosan, France
}

Abstract

Specific vulnerability estimations for groundwater resources are usually geographic information system-based (GIS) methods that establish spatial qualitative indexes which determine the sensitivity to infiltration of surface contaminants, but with little validation of the working hypothesis. On the other hand, lumped parameter models, such as the Residence Time Distribution (RTD), are used to predict temporal water quality changes in drinking water supply, but the lumped parameters do not incorporate the spatial variability of the land cover and use. At the interface between these two approaches, a GIS tool was developed to estimate the lumped parameters from the vulnerability mapping dataset. In this method the temporal evolution of groundwater quality is linked to the vulnerability concept on the basis of equivalent lumped parameters that account for the spatially distributed hydrodynamic characteristics of the overall unsaturated and saturated flow nets feeding the drinking water supply. This vulnerability mapping method can be validated by field observations of water concentrations. A test for atrazine specific vulnerability of the Val d'Orléans karstic aquifer demonstrates the reliability of this approach for groundwater contamination assessment. 
Keywords: Specific vulnerability, advection / dispersion, residence time distribution, equivalent parameters.

\section{Introduction}

The main tools for the management and the conservation of groundwater resources consist in characterizing the vulnerability of the aquifer used for drinking water. Intrinsic vulnerability uses physical characteristics as criteria to determine the sensitivity of groundwater to surface pollution. Most intrinsic vulnerability maps are multi-criteria, weighted and index-based, developed by Aller et al., (1987), Doerfliger et al., (1999), Petelet-Giraud et al., (2001) and Civita and De Maio (2004). The specific vulnerability of groundwater incorporates the physicochemical properties and their relationship with the natural environment as supplementary criteria in the vulnerability index estimation (Vrba and Zaporozec, 1994). These tools enable policies for the development of codes of practice for groundwater protection to be proposed (Escolero et al. 2002) and open up significant opportunities to enhance the efficacy of water vulnerability assessment tools by incorporating indicators and operational measures for social considerations (Plummer et al., 2012). While the area of use is huge, the index calculation method is limited because the weighting is usually arbitrarily chosen. These approaches are qualitative and highly subject to the hydrogeologist's interpretation (Panagopoulos et al., 2006).

Borehole vulnerability analysis was developed for drinking water supplying watersheds. This method completes the vulnerability index with the notions of distance, horizontal flow rate and transport to the target (borehole or spring) (Goldscheider and Popescu, 2003). In this framework, two types of vulnerability can be defined: a resource vulnerability which only takes vertical transfer into account, and a borehole vulnerability which incorporates the horizontal transfer into the borehole. The key parameters for the evaluation of specific vulnerability are the residence time of contaminants, their capacity of migration underground and the 
attenuation process. Some authors (Neukum et al., 2008; Anderson and Gosk 1987; Sadek and Abd El-Samie, 2001; Bakalowicz, 2005) suggested that a high vulnerability is related to a short residence time of the main part of the recharge. From these concepts, Brouyère (2001) relate a potential contamination to the transfer time, concentration level and duration of the phenomenon, plotted along the three axe of the cube. Jeannin et al. (2001) developed a program that relates field observations to concentration level, transfer time and duration. The model assumes an instantaneous release of a conservative contaminant at a given point on the land surface and simulates the resulting breakthrough curves at the outlet of each subsystem by means of the advection - dispersion equation, disregarding retardation and degradation processes (Zwahlen, 2003).

By linking the vulnerability index to physical parameters, the working hypothesis used in vulnerability mapping can be tested. Goldscheider et al. (2001) released different tracers at the land surface and observed the breakthrough at a target (spring), the travel time, the concentration and the tracer recovery rate to validate a vulnerability map. Holman et al. (2005) validated an intrinsic groundwater vulnerability method using a national nitrate database and some co-variance and variance analyses. Neukum et al. (2008) worked on the validation of a vulnerability map based on field investigation and column tracer experiments conducted on soil materials. The authors modelled tracer displacements using the advection - dispersion model and proposed a transit time distribution function of the tracer that depends on the geometric and hydraulic boundary conditions of the aquifer. Lasserre et al. (1999) developed a simple GIS-linked model to describe the groundwater transport of nitrates. For all these methods, developed to validate vulnerability criteria, the aim was to link surface land use with watershed hydrodynamic properties and water quality at the boreholes.

For time series analysis, several studies have applied an impulse response at the watershed scale for solute transport modeling purposes (Jury, 1982; Beltman et al., 1994; Barry and Parker, 1987; Molénat et al., 1999; Schwientek et al., 2009). The method consists in establishing a residence time distribution (RTD) to link pollutants at the surface of the 
watershed to the contaminant concentrations measured in the borehole. Related to the geometry of the aquifer, Jurgens et al., (2012) proposed six theoretical models, (derived from analytical solutions of the advection - dispersion reaction equation) to fit the impulse response with three lumped parameters. These parameters vary from one study to another, but the ones most widely used are the average residence time, the Peclet number and the rate of degradation. To evaluate groundwater quality trends, Visser et al. (2009) after a comparison between statistical, groundwater dating and deterministic modeling, showed that impulse response methods require little information about the physical system, but rather rely on the available data, which makes them suitable for application to a wide variety of systems.

Linking the spatial properties that determine the vulnerability and the temporal evolution of the water quality is a key point for water resource management. At the watershed scale, some semi-distributed models incorporate the soil surface properties to model water quality with a GIS dataset based on an impulse response, such as the SWAT model (Srinivasan and Arnold, 1994) or on a flow model such as Drainmod (Fernandez et al. 2006) MACRO (Larsbo and Jarvis, 2003) and STICS (Ledoux, 2003). For groundwater quality purposes, the flow paths must be analyzed in 3 dimensions but few tools are available to compute an impulse response from the spatially distributed 3D groundwater properties.

This paper proposes a method to calculate a RTD impulse response in aquifers based on spatial datasets used for specific vulnerability assessments. The spatial GIS vulnerability dataset corresponds to the thickness and hydrodynamic parameters of the geological formations found along the groundwater flow nets.

Based on the impulse response, which is characteristic of the watershed, the vulnerability index is defined as the mass ratio between the contaminants that exceeds a fixed threshold at the borehole and the injected mass. This makes it possible to map the relative vulnerability of each infiltration surface where contaminant application occurs. This approach includes residence times, dispersion and attenuation. Spatial vulnerability mapping is validated with GIS using the temporal evolution of the groundwater quality. 
108 The Residence Time Distribution (RTD) is a probability distribution function that describes the amount of time a fluid element can spend inside the column. After a pulse of mass $M$, its RTD is defined as:

$$
\mathrm{E}(\mathrm{t})=\frac{\mathrm{Q} \mathrm{C}(\mathrm{t})}{\mathrm{M}}=\frac{\mathrm{M}(\mathrm{t})}{\mathrm{M}}(\text { Equation 1) }
$$

112 Here $Q\left[\mathrm{~L}^{3} \cdot \mathrm{T}^{-1}\right]$ is the discharge flowing through the column.

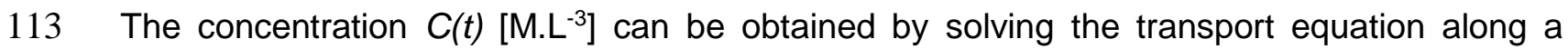

114 column open at both ends (Kreft and Zuber, 1978). For the transport of a pulse of mass $M$ in

115 a porous one-dimensional column (the transversal section is $A\left[\mathrm{~L}^{2}\right]$, the length $x$ and the column

116 water content is $\theta$ ), where water flow with a velocy $(\mathrm{u})$ there is many analytical solutions, most

117 of them use the non-dimensional Peclet number $(\mathrm{Pe})$, the average residence time $(\overline{\mathrm{t}})$ and the 118 rate of degradation $\lambda\left[\mathrm{T}^{-1}\right]$ of the contaminant during transport.

119 To assume that the column is open at both ends (Levenspiel 1962, Maloszewski and Zuber, 120 1982) enables to express the RTD as follow:

$$
\mathrm{E}(\mathrm{t})=\sqrt{\frac{\mathrm{Pe}}{4 \pi \mathrm{tt}}} \exp \left[-\frac{\mathrm{Pe}(\overline{\mathrm{t}}-\mathrm{t})^{2}}{4 \mathrm{t} t}\right] \exp [-\lambda \mathrm{t}] \quad(\text { Equation 2) }
$$

122 The contaminant transport through the column is described with only three parameters and no

123 assumption is made on the laminar, turbulent, unsaturated or saturated nature of the flows.

124 Degradation and delay are taken into account with $\lambda$ and $\bar{t}$. If no reaction occurs, $\bar{t}$ is the same 125 as the average residence time of the water in the column.

126 2.1. RTD for a column with multi layers. 
128 For the transport of a pulse, the mean residence time $\bar{t}[T]$ of the contaminant in the column

129 can be defined either with the $C(t)$ curve or as the ratio between the water flux $(\mathrm{u})$ and the 130 stored water $(\theta \mathrm{L})$ :

$$
\overline{\mathrm{t}}=\frac{\int_{0}^{\infty} \mathrm{tC}(\mathrm{t}) \mathrm{dt}}{\int_{0}^{\infty} \mathrm{C}(\mathrm{t}) \mathrm{dt}}=\frac{\mathrm{u}}{\theta \mathrm{L}} \quad \text { (Equation 3) }
$$

132 Another important descriptor of the $C(t)$ curve is its variance:

$$
\sigma^{2}=\frac{\int_{0}^{\infty}(\mathrm{t}-\overline{\mathrm{t}})^{2} \mathrm{C}(\mathrm{t}) \mathrm{dt}}{\int_{0}^{\infty} \mathrm{C}(\mathrm{t}) \mathrm{dt}} \text { (Equation 4) }
$$

134 In decomposing the borehole watershed into $n$ parallel flow nets. This reduces the non-linear

135 three-dimensional problem to a linear one-dimensional one. The water and the contaminant 136 mass which infiltrate the ground enter through the various $i$ layers of the aquifer where the 137 hydro-dispersive properties can vary. They flow through the $i$ layers until the borehole, 138 following the flow nets. For every $n$ flow net, the $i$ layers are considered to be independent 139 columns characterized by the average residence time $\bar{t}_{n, i}$ and the Peclet number $P e_{n, i}$.

140 For $i$ serial layers, equivalent properties can be calculated. The mean residence time for the $141 n^{\text {th }}$ flow net, where contaminant flows through $i$ serial columns, is:

$$
\left\langle\overline{\mathrm{t}}_{\mathrm{n}}\right\rangle=\sum_{1}^{\mathrm{i}} \overline{\mathrm{t}}_{\mathrm{n}, \mathrm{i}} \text { (Equation 5) }
$$

143 In 1959, Aris showed that, in the case of an infinite column, the change in the variance

144 (equation 4) between two points can be described as:

$$
\frac{\Delta \sigma^{2}}{\overline{\mathrm{t}}^{2}}=\frac{2}{\mathrm{Pe}} \text { (Equation 6) }
$$

146 Thus, if this relation is extended to $i$ serial columns, the equivalent Peclet number $<P e_{n}>$ for

147 the $n^{\text {th }}$ flow net, can be defined as:

$$
\frac{\left\langle\mathrm{Pe}_{\mathrm{n}}\right\rangle}{2}=\frac{\left\langle\overline{\mathrm{t}}_{\mathrm{n}}^{2}\right\rangle}{\Delta \sigma_{\mathrm{n}, \mathrm{i}^{-} \ldots-\Delta \sigma_{\mathrm{n}, 1}^{2}}^{2}}=\frac{\left\langle\overline{\mathrm{t}}_{\mathrm{n}}^{2}\right\rangle}{\sum_{1}^{\mathrm{i}}\left(\frac{2 \overline{\mathrm{t}}_{\mathrm{n}, \mathrm{i}}^{2}}{\mathrm{Pe}_{\mathrm{n}, \mathrm{i}}}\right)} \text { (Equation 7) }
$$

149 This formulation enables the residence time distribution $E_{\mathrm{n}(\mathrm{t})}$ at the output of the $n^{\text {th }}$ flow net to 150 be described, using an equivalent average residence time and an equivalent Peclet number. 
151 The mass of contaminant at the borehole is the sum of the mass arriving through the $n$ flow

152 nets. The RTD becomes:

$$
E_{(t)}=\frac{\sum_{1}^{n}\left[E_{n(t)} M_{n}\right]}{\sum_{1}^{n} M_{n}} \text { (Equation 8) }
$$

\subsubsection{Water and contaminant fluxes at the upper boundary}

158 The mass of contaminants entering the aquifer is considered to be the mass $M[\mathrm{M}]$ flowing

159 under the organic soil zone. Published data on the rate of contaminant seeping under the soil

160 (a) [/] compared to the initial pulverized mass $M_{0}$ can be used:

$$
M=M_{0} * a(\text { Equation 9) }
$$

162 The delay between pulverization and exportation under the roots in the soil is considered to 163 be very small with respect to the average residence time used to describe groundwater flows.

\subsubsection{Calculation of average residence times and Peclet numbers}

165 First, the surface watershed of the borehole is discretized into unitary surfaces. The aquifer

166 volume is divided into an unsaturated zone with vertical flows, and a saturated zone with

167 horizontal flows. The contaminants flow first vertically toward the unsaturated zone, and then

168 horizontally towards the borehole. Based on the groundwater head maps, the flow direction

169 and the flow length $(L)$ was defined for each of the $n$ flow nets of the system. The calculation

170 was carried out with the GIS ARCGIS ${ }^{\circledR}$ toolbox. For the unsaturated zone, the flow length $L$ is

171 simply calculated by the difference between the topographic and water head level.

172 Along each flow net, $i$ columns can be discretized based on the 3D geological dataset. For

173 each flow net $n$ and $i$ column, the equivalent Peclet number and the average residence time

174 can be computed from with the hydrogeological dataset $u, D, \theta$.

175 The equivalent parameters can be estimated using the GIS tool before being injected into the 176 RTD equation (Equation 8). 
178

\subsection{Simulation of water quality by convolution}

If we consider the various periods of infiltration as a sum of brief injections of mass $M$ entering the column at time $t^{\prime}$, the concentration in the borehole $C_{(t)}$ can be deduced from the RTD:

$$
\mathrm{C}_{(\mathrm{t})}=\frac{1}{\mathrm{Q}} \int_{-\infty}^{\mathrm{t}} \mathrm{M}_{\mathrm{t}} \mathrm{E}_{\left(\mathrm{t}-\mathrm{t}^{\prime}\right)} \mathrm{e}^{-\lambda\left(\mathrm{t}-\mathrm{t}^{\prime}\right)} \mathrm{dt^{ \prime }}(\text { Equation 10) }
$$

The history of the dissolved masses injected in the watershed $(M)$ and the steady state average discharge of water across the borehole $(Q)$ must be implemented. The Nash-Sutcliffe coefficient E (Nash and Sutcliffe, 1970) was used to assess the efficiency of the RTD model using equivalent parameters.

\subsection{Analogy between RTD, vulnerability and risk indexes} The equivalent RTD for each flow net represents the mass arriving at the borehole for an injected mass equal to 1 . Depending on the value of the equivalent parameters, and on the discharge $Q_{\mathrm{n}}$ for the $n^{\text {th }}$ flow net, the concentrations obtained make it possible to identify flow nets showing concentrations higher than a threshold (LR) represented by the dashed line in Fig. 1 while other flow nets present concentrations below the threshold. The spatialized grid of equivalent parameters locates the surfaces which contribute to the over-concentration measured at the groundwater borehole, making it possible to prioritize the various surfaces in terms of borehole vulnerability and/or risk.

Using datasets of $M$ values, the specific risk index $(I)$ is defined as the rate between the mass above the threshold $M_{d}$ (Fig. 1) and the mass flowing under the roots $M$. (equation 16).

$$
\mathrm{I}=\frac{\mathrm{M}_{\mathrm{d}}}{\mathrm{M}}=\frac{\int_{\mathrm{a}}^{\mathrm{b}}\left[\frac{\mathrm{E}(\mathrm{t}) \mathrm{M}}{\mathrm{Q}_{\mathrm{n}}}-\mathrm{LR}\right] \mathrm{dt}}{\mathrm{M}}(\text { Equation 11) }
$$

The boundaries $a$ and $b$ are defined in Fig 1 as the intercepts between the $C(t)$ curve and the fixed threshold. So, the specific risk index $I$ is defined as the percentage of the applied contaminant mass which will reach the borehole above a given threshold. If $M=1$ for the entire watershed and the threshold has a low value, then equation 11 becomes an intrinsic vulnerability index. 


\section{3. Study site and data}

205 The proposed model was tested on the Val d'Orléans karstic system, which has a wide range 206 of flow velocities. This section presents the dataset required to apply the proposed 207 methodology, and the various existing ways to compile this database.

\subsection{The Val d'Orléans}

210 The Val d'Orléans is located southeast of Orléans city, in the alluvial plain of the Loire river 211 which corresponds to a depression of the main river bed. The length of this alluvial plain is 212 about $40 \mathrm{~km}$ and its maximum width reaches $7 \mathrm{~km}$ in its central part (Fig. 2).

\section{3.1.1. Pedology}

214 Inside the protection zone (Fig.2A), clays In soil represent about 0 to $250 \mathrm{~g} / \mathrm{kg}$. The sand 215 contents in silt (100 to $250 \mathrm{~g} / \mathrm{kg}$ ) and organic carbon ( 0 to $10 \mathrm{~g} / \mathrm{kg}$ ) are quite homogeneous 216 (BDAT-GISSOL-INRA, 2014). This database shows a low content of clays and sands in the 217 center and east of the perimeter and higher contents in the west zone. The values range 218 respectively from 0 to $100 \mathrm{~g} / \mathrm{kg}$ and from 100 to $250 \mathrm{~g} / \mathrm{kg}$.

\subsubsection{Geology}

221 The geology in this sector results from a major and regular marine sedimentation 222 (transgression and regression phenomena), that started during the Trias and lasted until the 223 beginning of the Tertiary (Eocene). White chalk with flint and detritical formations constitute 224 the base of the geological formations of the Val d'Orléans. In the middle of the Tertiary 225 (Oligocene, Aquitanien), a sedimentation of lacustrine origin formed the limestones of Beauce, 226 interrupted with marly formations. In the second part of the Tertiary (Burdigalien), marls and 227 sands were deposited, before being covered by fluvial (Quaternary) alluviums of the Loire 228 (Auterives et al. 2014). For this study, only the sedimentary formations of lacustrine origin 
which began during the Oligocene were of interest because it is the main aquifer. A karstic network developed in the Beauce limestones, generally captive, either under the alluvial formation or under the Burdigalien marls. A probability map of the karstic network was proposed by Auterives et al., 2014.

This karstic network is supplied by surface water coming from the Loire river which infiltrates at point sources (Albéric, 2004) in the area of Jargeau (Fig.2A) and by diffuse infiltration through the alluvial plain located mainly in the river bed. Some of these karstic conduits outflow downstream the Val d'Orléans where springs contribute to the establishment of the Loiret river (Lepiller, 2006). Three drinking water boreholes are located within or close to the karstic network (Fig. 2A). Based on the water quality data (isotopes and major elements) of the Loire water, the local surface waters and the Loiret spring waters, Joigneaux (2011) revealed that $80 \%$ of the Loiret spring waters are composed of Loire water, the remainder being local surface waters. Mixing is controlled by the hydrological conditions of the Loire river.

The groundwater vulnerability to diffuse agricultural pollution was estimated in the protection zone of the three boreholes (Fig.2A).

\subsubsection{Water flux and contaminants below the root zone}

The discharge values $Q$ arise from the hydrological balance. This assessment was made by various authors such as Chéry (1983), Livrozet (1984), Lepiller (2006), Lelong and Jozja (2008), Gutierrez and Binet (2010). Three different flow values were considered according to three hydrological scenarios. These three scenarios represent the minimal, maximal and average flows that transit through the system. The minimal flow can be estimated from the lowest contribution of the flow from the Loire river and the lowest contribution of impluvium in the total hydrological balance assessment. The minimal value of the contribution of the river Loire loss was estimated at $5 \mathrm{~m}^{3} / \mathrm{s}$ (Martin and Noyer, 2003; Gutierrez and Binet, 2010), whereas the lowest flow from the impluvium calculated by MACRO (Larsbo and Jarvis, 2003) 
255 and calibrated for the Val d'Orleans is $0.100 \mathrm{~m} /$ year (Footways/Geo-Hyd, 2013). Thus, the

256 minimal contribution in water supplied to the system was estimated at $186.10^{6} \mathrm{~m}^{3} /$ year. $15 \%$

257 of the water comes from diffuse infiltration.

258 Concerning the average flow, the volume of the Loire loss to the Val d'Orléans aquifer, for an 259 average year, was estimated by hydrological balance at $363.10^{6} \mathrm{~m}^{3} / \mathrm{year}$. The results of 260 models that estimate the effective rain, stemming from the impluvium, suggested a flow of $2610.191 \mathrm{~m} /$ year (Joigneaux et al., 2011). The average flow transiting through the system is 262 estimated to be $423.10^{6} \mathrm{~m}^{3} /$ year. Here again, $15 \%$ of the water comes from diffuse infiltration. 263 The proposed RTD model was tested and calibrated for the application of atrazine, which was 264 sprayed between 1960 and 2003 on the maize crops. The reason for this choice is the 265 quantitative availability of analyses done on the three Val d'Orléans boreholes, which revealed 266 the presence of atrazine from the 1990s to 2004, showing, with a quarterly sampling frequency, an erratic response with values ranging from 0 to $0.3 \mu \mathrm{g} / \mathrm{L}$. Atrazine concentration in the Loire 268 river has been below the detection limit since the beginning of the century. In the 1990s, 269 concentrations reached $0.3 \mu \mathrm{g} / \mathrm{L}$ (Joigneaux, 2011). It is considered that the totality of the 270 atrazine concentration analysed at the three Val d'Orléans boreholes comes from diffuse 271 infiltration through the alluvial plain. The Loire river dilutes the fluxes.

272 The localization of the maize crops was mapped in 2010 and was assumed to be constant 273 through time (Fig. 2A). The atrazine masses injected during more than 40 years were 274 estimated from the history of agricultural practices recorded in various ways, such as 275 questionnaires collected by agricultural associations. Atrazine was applied by spraying, 276 generally made once a year, in April. The quantities of atrazine applied decreased over time, $277\left(2.5 \mathrm{~kg} / \mathrm{ha} /\right.$ year in the $70^{\text {th }}, 1.5$ in the $80^{\text {th }}, 1$ betwwen 1991 to $1998,0.75$ in 1999 and 2000 and 2780.5 betwwen 2000 to 2003 ) due to increasing constraints on the use of this herbicide, until it 279 was banned in 2003. Some studies show that pesticides such as atrazine can have an export 280 percentage up to 4 to $2075 \%$ (Flury, 1996). Naturally, these ranges of values vary according 
281 to the geo-hydro- morphological context of the site, but are mostly between 0.1 to $3 \%$

282 (Wauchope, 1978; Flury, 1996; Voltz and Louchart, 2001).

\subsection{Field data for RTD estimation}

285 Establishing the RTD requires data concerning the hydrodynamic characteristics of the aquifer

286 (Table 1). Each hydrodynamic parameter is attributed to each surface of the grid area (250 $\mathrm{m}$ 287 by $250 \mathrm{~m}$, Fig. 2A).

288 The hydrodynamic characteristics of the unsaturated zone (UZ) were attributed according to 289 the lithology of the four profiles already defined (sand (SD), sand and limestone (SD/LM), sand 290 and clay $(S D / C L)$ and clay and sand (CL/SD)). The length of flows are known from the 291 topographic elevation nimus the aquifer water head (Desprez in 1967).

292 In the saturated zone (Table 1), 2000 borehole logs were analysed. Alluvium, limestone and 293 karstified limestones were observed in the area (Auterives et al. 2014). In a saturated context, 294 the water content is equal to the porosity.

\subsubsection{Atrazine in groundwater}

296 Estimating the specific vulnerability requires knowledge of the specific behaviour of the studied

297 contaminants. For atrazine, a 10-year database is available, with more than 110

298 measurements. The atrazine degradation rate is known to be 0.4 [month ${ }^{-1}$ ] (IUPAC, 2013) and 299 rate of infiltration $(a)$ was estimated at about 0.05 (Kladivko et al., 1991).

302 Uncertainty on the parameterization was explored by calculating various RTDs to assess the

303 impact of parameterization on the results. Before estimating the vulnerability mapping with the

304 RTD model, various parameter values were tested to observe the variability of the RTD. Here,

305 three tests concerning the unsaturated zone (UZ) are presented, as this uncertainty accounts 306 for the strongest error source in the calculation. The parametric tests presented will focus on 307 the UZ profiles spatialisation. Three models are presented in the Results section: 
1. RTD_T1: For this scenario, it was considered that the UZ consisted of only one filtering facies of sand (Profile SD) and no vertical karstic conduits.

2. RTD_T2: This configuration corresponds to the results of the spatial analysis of the UZ profiles (best fit).

3. RTD_T3: This scenario uses the same hydrodynamic characteristics as T1 but adds 34 vertical karstic conduits, positioned according to the karstic network and a database cavity, assuming that not all the vertical conduits are necessarily known.

\section{Results}

\subsection{Equivalent Peclet numbers and average residence times}

The spatial distributions of the hydrodynamic parameters used for the calculation of the equivalent parameters and the intermediate calculations for RTD are presented in Fig. 2B. The data concern the four types of profiles (Table1) and the limestone karst aquifer layer in the saturated zone. The alluvium aquifer located above the limestone aquifer is not shown in Fig. $2 \mathrm{~B}$ but was nevertheless taken into account in the calculation of the equivalent parameters. The Fig. 2B and $\mathrm{C}$ shows the spatialized values $\left(V_{d}, L, \theta, n_{e}\right.$ and $\left.\alpha\right)$ from the $\mathrm{UZ}$ and $\mathrm{SZ}$ layers. The second column gives the equivalent parameters (average residence times and equivalent Peclet numbers) for the $n$ flow nets starting from the $\mathrm{n}$ grid cells and determined by equations 10 and 12.

\subsection{RTD Calculations}

The time discretization unit selected for contamimant transport was one month. This is consistent with the assumption of steady-state conditions for the hydrology.

Fig. 2D shows the residence time distribution calculated from equation 13 . The three scenarios illustrate the variability of the results when parameters are varied in the unsaturated zone. The parameters described in Table 1 correspond to the RTD_2 scenario. In this highly karstified area, the residence times are short, less than 12 months, and the average residence time is 
333 about 2 - 4 months. The two extreme cases (Fig. 3) show that the intensity of the concentration

334 peak can be twice as high in a karstic system compared to sand.

335

336

337

338

339

340

341

342

\subsection{Concentration calculated at the water borehole by the RTD model}

Figure 4 shows the concentration at the water borehole calculated by the RTD model. The average flow reproduces the maximum groundwater concentrations in atrazine at the borehole. The Nash-Sutcliffe coefficient was determined for the period 1990 to 2005 . The value reaches 0.70 .

\subsection{Vulnerability and risk mapping}

A vulnerability map can be computed, considering that each flow net receives a contaminant mass $M=1$. The vulnerability can be estimated by prioritizing all the calculated RTDs (equation 16). Combining the vulnerability map with a hazard map (Fig. 2E) gives a risk map for atrazine in the watershed. The results obtained are scaled on a range from 0 to 100.

Compared to traditional vulnerability mapping, this approach adds the notion of hydraulic distance to from the borehole. Surfaces with a high index (in red) are not spatially the closest to the borehole.

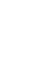

\section{Discussion}

The Nash-Sutcliffe coefficient suggests that the implementation of the equations, the parameterization and the strong hypothesis proposed in the RTD model seem acceptable for a risk assessment approach.

Concerning the mass of Atrazine applied on the field, the survey and the coefficient used to evaluate the loss in organic soil give results in terms of water concentration at the 
borehole in the same order of magnitude as the concentrations observed. The range of uncertainty on the discharge $(Q)$ and on Atrazine input (M) means that one can compensate the other, and with the given data, it is difficult to determine where the greatest source of error in our calculation lies. The uncertainty on the vertical conduit location is a key parameter for a relevant vulnerability assessment.

The range of equivalent Peclet numbers and average residence times found for this aquifer is wide. That is why a karst system was chosen to test this model.

The hydrology was assumed to be steady state. Although many authors point out that water exchange between conduits and the surrounding rock drives the water quality at the karstic outlet (Charmoille et al., 2009), this strong hypothesis was made for large time steps, such as months or years. In these conditions, it is preferable to describe the average behaviour of the system, which is easier to use for risk assessment. High or low water stages can be estimated from the extreme discharge values (Fig.3).

Concerning the contaminant transport, the progressive decrease in atrazine concentration observed at the borehole is correctly described by the model and corresponds to the decrease in the quantites of atrazine applied to the maize crops (Table 1). The apparently erratic distribution of the atrazine concentrations observed is explained by the pulses of atrazine occurring 2 or 3 months after the injection periods. These results help to rationalize sampling campaigns and to ensure a better management of water resources.

No storage was observed and advective flow control was observed in this highly transitive system. However, a temporal shift of a few weeks (X axis) can be observed. The calculated concentrations appear before the observed ones. We hypothesize that the origin of this phenomenon is the uncertainty concerning the exact period of application. In our case, atrazine application was considered to occur once a year, in April, but in reality applications may have varied depending on the weather conditions. 
383 The RTD model, based on literature datasets, made it possible to estimate a specific

384 vulnerability, which can then be validated by field data. Fig. $2 \mathrm{E}$ can be validated by time 385 series of contaminants observed in the water supply. There is no single solution that can fit 386 the concentration time series at the borehole. While many spatial distributions can lead to 387 the same lumped parameters, the advantage of the proposed approach is that it can test 388 whether the working hypotheses are sustainable. This is an improvement over the usual 389 method of vulnerability and risk assessment, and avoids the use of numerical groundwater 390 flow models that are generally over-parametrized.

\section{6. Conclusions}

393 The specific vulnerability index locates the potential source of groundwater quality deterioration, but most assessment methods are qualitative. The Residence Time Distribution

395 model can address temporal and transient aspects of contaminant spreading and represent

396 them in a semi-quantitative manner. Such an approach makes it possible to establish a spatial 397 risk or vulnerability indexes validated by water quality changes at the borehole. The dataset 398 used in this method is commonly found in vulnerability studies. By using equivalent parameters 399 to take the characteristics of each layer into consideration, the spatial complexity of the 400 watershed can be reduced to an impulse response. The method based on the probability 401 distribution of residence times is a semi-objective method that can help groundwater managers 402 and decision-makers based on a physical approach to vulnerability assessment. The risk 403 mapped with this methodology gives the opportunity to test the efficiency of land practice 404 scenarios on the quality of the groundwater catchments.

\section{Acknowledgements}

407 This work is part of the PhD project supported by GEO-HYD (Antea members) and a national 408 grant from the National Research and Technology Association (ANRT - CIFRE). 
409 The database used was made available by the INSU/CNRS national observatory of karstic 410 aquifers, SNO KARST.

411 


\section{References}

413 Albéric P (2004) River backflooding into a karst resurgence (Loiret, France). Journal of $414 \quad$ Hydrology 286: 194-202.

415 Aller L, Bennett T, Lehr JH, Petty RJ, Hackett G (1987) DRASTIC: a standardized system for 416 evaluating groundwater pollution potential using hydrogeological settings. US 417 Environmental Protection Agency. Washington, DC, USA.

418 Andersen L, Gosk E (1987) Applicability of vulnerability maps: Vulnerability of soil and 419 groundwater to pollutants, Proceedings and Information. TNO Committee on Hydrological $420 \quad$ Research 28: 321-332

421 Aris R (1959) On the dispersion of a solute by diffusion, convection and exchange between 422 phases. Chemical reaction Engineering, doi: A252

423 Auterives C, Binet S, Albéric P (2014) Inferred conduit network geometry from geological 424 evidences and water-head in a fluvio-karstic system (Val d'Orleans, France). Environment 425 Earth Sciences. doi: 10.1007/978-3-319-06139-9_3

426 Bakalowicz M (2005) Karst groundwater: a challenge for new resources. Hydrogeology Journal. 427 doi: 10.1007/s10040-004-0402-9

428 Barry DA, Parker JC (1987) Approximations for solute transport through porous media with flow 429 transverse to layering. Transport in porous media, 2: 65-82

430 BDAT-GISSOL-INRA (2014). http://www.gissol.fr/programme/bdat/bdat.php. Accessed 10 $431 \quad$ December 2014

432 Beltman WHJ, Boesten JJTI, Van der Zee SEATM (1994) Analytical modelling of pesticide 433 transport from the soil surface to a drinking water well. Journal of Hydrology 169: 209-228 
434 Binet S, Motellica M, Touze S, Bru K, Klinka T (2014) Water and Acrylamide monomer transfer 435 rates from a settling basin to groundwaters. Environmental Science and Pollution Research. 436 doi: $10.1007 / \mathrm{s} 001090000086$

437 Brouyère S (2001) Modelling of dual porosity media: comparison of different techniques and 438 evaluation on the impact on plume transport simulations. PhD Thesis Liège University

439 Chéry J (1983) Etude hydrochimique d'un aquifère karstique alimenté par perte de cours d'eau 440 (La Loire): Le système des calcaires de Beauce sous le Val d'Orléans. PhD Thesis Orléans $441 \quad$ University

442 Civita M, De Maio M (2004) Assessing and mapping groundwater vulnerability to contamination:

443 The Italian “combined” approach. Geofisica Internacional 4: 513-532

444 Charmoille A, Binet S, Bertrand C, Guglielmi Y, Mudry J (2009) Hydraulic interactions between 445 fractures and bedding planes in a carbonate aquifer studied by means of experimentally 446 induced water-table fluctuations Coaraze experimental site, southeastern France. $447 \quad$ Hydrogeology journal 17: 1607-1616

448 Desprez N (1967) Inventaire et étude hydrogéologique du Val d'Orléans. Rapport BRGM D$449 \quad$ SGR-67-A21

450 Doerfliger N, Jeannin PY, Zwahlen F (1999) Water vulnerability assessment in karst 451 environments: a new method of defining protection areas using a multi-attribute approach 452 and GIS tools (EPIK method). Environmental Geology 39: 165-176

453 Escolero OA, Marin LE, Steinich B, Pacheco AJ, Cabrera SA, Alcocer J, (2002) Development 454 of a Protection Strategy of Karst Limestone Aquifers: The Merida Yucatan, Mexico Case 455 Study. Water Resour Manag 16: 351-367 
456 Fernandez GP, Chescheir GM, Skaggs RW, Amatya DM (2006) DRAINMOD - GIS: A lumped 457 parameter watershed scale drainage and water quality model. Agricultural Water $458 \quad$ Management. doi: 10.1016/j.agwat.2005.03.004

459 Flury M (1996) Experimental evidence of transport of pesticides through field soils - A review. $460 \quad$ Journal of Environmental Quality 25: 25-45

461 Footways/Géo-Hyd (2013) Application Phyto'Scope au Val d'Orléans: Outils d'évaluation du 462 transfert des produits phytosanitaires de leurs zones d'application vers les eaux de surface et $463 \quad$ les eaux souterraines

464 Gelhar LW (1992) A critical review of data on field-Scale Dispersion in Aquifers. Water $465 \quad$ resources research 7: 1955-1974

466 Goldscheider N, Hötzl H, Fries W, Jordan P (2001) Validation of a vulnerability map (EPIK) 467 with tracer tests. 7th Conference on Limestone Hydrology and Fissured Media. Sci.Tech 468 Environ Mém. 13: 167-170

469 Goldscheider N, Popescu C (2003) Vulnerability and risk mapping for the protection of carbonate 470 (karst) aquifer. European commission Directorate - General for Research, pp 320

471 Gutierrez A, Binet S (2010) La Loire souterraine: circulations karstiques dans le Val d'Orléans. $472 \quad$ Géosciences $12: 42-53$

473 Holman IP, Palmer RC, Bellamy PH, Hollis JM (2005) Validation of an intrinsic groundwater 474 pollution vulnerability methodology using a national nitrate database. Journal of Hydrology. 475 doi: $10.1007 / \mathrm{s} 10040-005-0439-4$

476 IUPAC (2013) Global availability of information on agrochemicals. University of Hertfordshire. 
478 Jeannin PY, Cornaton F, Zwahlen F, \& Perrochet P (2001) VULK: a tool for intrinsic 479 vulnerability assessment and validation. 7th Conference on Limestone. Hydrology and $480 \quad$ Fissured Media, pp 185-190

481 Joigneaux E (2011) Etat qualitatif des eaux de la nappe du Val d'Orléans; Impact du changement 482 climatique et gestion durable de la ressource. PhD Thesis Orléans University

483 Joigneaux E, Albéric P, Pauwels H, Pagé C, Terray L, Bruand A (2011) Impact of climate change 484 on groundwater point discharge: backflooding of karstic springs (Loiret, France). Hydrol. $485 \quad$ Earth Syst. Sci. 15: 2459-2470

486 Joodi AS, Sizaret S, Binet S, Bruand A, Alberic P, Lepiller M (2009) Development of a Darcy487 Brinkman model to simulate water flow and tracer transport in a heterogeneous karstic aquifer 488 (Val d'Orléans, France). Hydrogeology journal 18: 295-309

489 Jurgens BC, Böhlke JK, Eberts SM (2012) Tracer LPM (Version 1): An Excel ® workbook for 490 interpreting groundwater age distributions from environmental tracer data. US Geological $491 \quad$ Survey Techniques and Methods Report 4-F3, USA

492 Jury A (1982) Simulation of solute transport using a transfer function model. Water Resources $493 \quad$ Research 2: 363-368

494 Kladivko EJ, Van Scoyoc GE, Monke EJ, Oates KM, Pask W (1991) Pesticide and nutrient 495 movement into subsurface tile drains on a silt loam soil in Indiana. Journal of Environmental 496 Quality 20: 264-270

497 Kreft A, Zuber A (1978) On the physical meaning of the dispersion equation and its solutions for 498 different initial and boundary conditions. Chemical Engineering Science 33: 1471-1480 499 Larsbo M, Jarvis N (2003) A model of water flow and solute transport in macroporous soil. 500 Technical description. Studies in the biogeophysical Environment. Swedish 
501 Lasserre F, Razack M, Banton O (1999) A GIS-linked model for the assessment of nitrate 502 contamination in groundwater. Journal of Hydrology 224: 81-90

503 Ledoux E (2003) Modèles mathématiques en hydrogéologie. Document du Centre d'Information 504 Géologique Ecole Nationale Supérieur des Mines de Paris, Paris

505 Lelong F, Jojza N (2008) Fonctionnement du système karstique du Val d'Orléans: les acquis, les 506 interrogations. CFH - Colloque hydrogéologie karst au travers des travaux de Michel $507 \quad$ Lepiller, Orléans

508 Lepiller M (2006) Le Val d'Orléans. Aquifère et eaux souterraines en France (BRGM), pp $509 \quad 200-214$

510 Levenspiel O (1962) Chemical reaction engineering. New York

511 Li C, Ren L (2011) Estimation of unsaturated soil hydraulic parameters using the ensemble 512 kalman filter. Vadoze Zone Journal 10: 1205-1227

513 Livrozet E (1984) Influence des apports de la Loire sur la qualité bactériologique et chimique de 514 l'aquifère karstique du Val d'Orléans. PhD Thesis Orléans University

515 Maloszewski P Zuber A (1982) Determining the turnover time of groundwater systems with the 516 aid of environmental tracers - 1. Models and their applicability. Journal of hydrology 57: $207-231$

518 Martin JC, Noyer ML (2003) Caractérisation du risque d'inondation par remontée de nappe sur 519 le Val d'Orléans. BRGM, Orléans

520 Molénat J, Davy P, Gascuel-Odoux C, Durand P (1999) Study of three subsurface hydrologic $521 \quad$ systems based on spectral and cross-spectral analysis of time series. Journal of Hydrology 222: $152-164$

523 Nash JE, Sutcliffe JV (1970) River flow forecasting through conceptual models part I - A 524 discussion of principles. Journal of hydrology 10: 282-290 
525 Neukum C, Hötzl H, Himmelsbach T (2008) Validation of vulnerability mapping methods by 526 field investigations and numerical modelling. Hydrogeology Journal. doi:10.1007/s10040007-0249-y

528 Panagopoulos GP, Antonakos AK, Lambrakis NJ (2006) Optimization of the DRASTIC method 529 for groundwater vulnerability assessment via the use of simple statistical methods and GIS.

$530 \quad$ Hydrogeology Journal 14: 894-911

531 Petelet-Giraud E, Doerfliger N, Crochet P (2001) RISKE: Méthode d'évaluation multicritère de 532 la cartographie de la vulnérabilité des aquifères karstiques. Application aux systèmes des 533 Fontanilles et Cent-Fonts (Hérault, France). Hydrogéologie 4: 71-88

534 Plummer R, de Loë R, Armitage D, (2012) A Systematic Review of Water Vulnerability 535 Assessment Tools. Water Resour. Manag. 26: 4327-4346

536 Sadek MA, Abd El-Samie SG (2001) Pollution vulnerability of the Quaternary aquifer near Cairo, 537 Egypt, as indicated by isotopes and hydrochemistry. Hydrogeology Journal. doi: $538 \quad 10.1007 / \mathrm{s} 100400100125$

539 Schwientek P, Maloszewski P, Einsiedl F (2009) Effect of the unsaturated zone thickness on the 540 distribution of water mean transit times in a porous aquifer. Journal of Hydrology 373: $541 \quad 516-526$

542 Šimůnek J, Šejna M, Sakai M, Van Genuchten M Th. (2008) The HYDRUS-1D Software 543 Package for Simulating the One-Dimensional Movement of Water, Heat, and Multiple $544 \quad$ Solutes in Variably-Saturated Media. Riverside, California

545 Srinivasan R, Arnold JG (1994) Integration of basin-scale water quality model with GIS. Water resources 30: 453-462 
547 Visser A, Dubus IG, Broes HP, Brouyère S, Korcz M, Orban P (2009) Comparison of methods 548 for the detection and extrapolation of trends in groundwater quality. Journal of

549 Environmental Monitoring. doi:10.1039/B905926A

550 Voltz M, Louchart X (2001) Les facteurs clés de transfert des produits phytosanitaires vers les 551 eaux de surface. Ingénieries - Phytosanitaires, pp 45-54

552 Vrba J, Zaporozec A (1994) Guidebook on Mapping Groundwater Vulnerability. USA

553 Wauchope RD (1978) The pesticide Content of Surface Water Draining from Agricultural Fields.

554 Journal of Environmental Quality 7: 459-472

555 Zwahlen F et al (2003) COST Action 620 - Vulnerability and risk mapping for the protection of 556 carbonate (karst) aquifers. Final Report. European Cooperation in the field of scientific and 557 technical research (COST Action 620)

\section{TABLE CAPTIONS}

\begin{tabular}{|c|c|c|c|c|}
\hline & Velocity (Vd) & Water content (q) & Longitudinal dispersivity coefficient ( $\alpha$ L) & Length of flow (L) \\
\hline Units & {$[\mathrm{m} / \mathrm{s}]$} & {$[-]$} & {$[\mathrm{m}]$} & {$[\mathrm{m}]$} \\
\hline Unsaturated profiles SD & $2.31 .10^{-7}$ & 0.33 & 0.4 & 1.49 to 16.49 \\
\hline Unsaturated profiles SD/LM & $1.00 .10^{-8}$ & 0.4 & 0.4 & 4.22 to 9.39 \\
\hline Unsaturated profiles SD/CL & $3.50 .10^{-9}$ & 0.5 & 0.5 & 1.99 to 13.5 \\
\hline Unsaturated profiles CL/SD & $3.50 .10^{-9}$ & 0.6 & 0.5 & 2.05 to 10.37 \\
\hline Saturated alluvium & $9.10^{-8}$ to $6.10^{-4}$ & 0.15 & 20 & 1 to 14467 \\
\hline Saturated limestone & $8.10^{-8}$ to $2.10^{-2}$ & 0.3 & 2.5 & 1 to 10139 \\
\hline Saturated kartic conduit & $8.10^{-8}$ to $2.10^{-2}$ & 1 & 38 & 1 to 10139 \\
\hline References & $\begin{array}{l}\text { Li and Ren (2011), } \\
\text { Joodi et al (2009) }\end{array}$ & $\begin{array}{l}\text { Simunek et al. } \\
\qquad(2008)\end{array}$ & $\begin{array}{l}\text { Simunek et al. (2008) and Gelhar (1992), } \\
\text { Binet et al. (2014) }\end{array}$ & Desprez, 1967 \\
\hline
\end{tabular}

560 Table1: Hydrodynamic characteristics of the zone 


\section{FIGURE CAPTIONS}

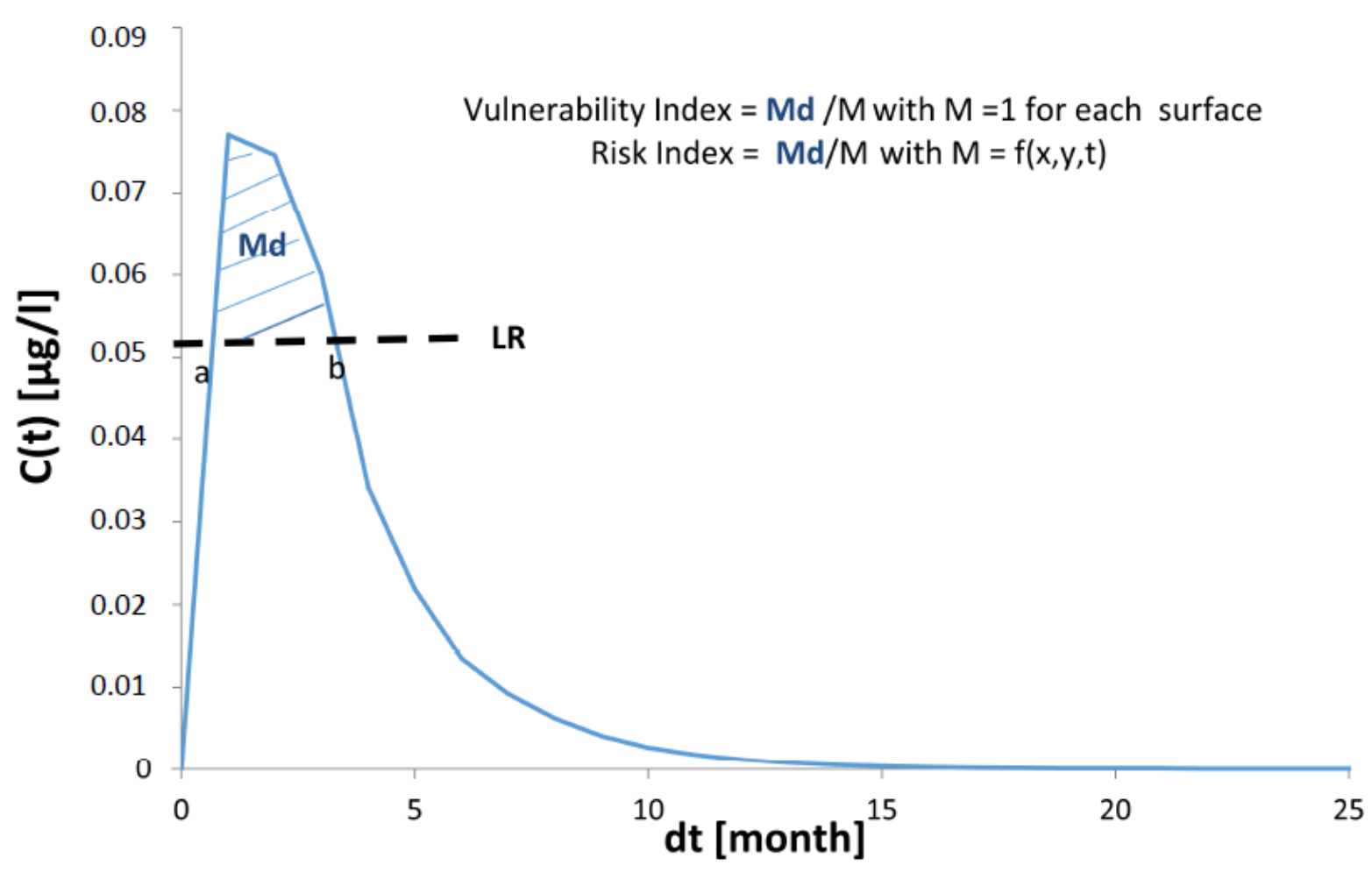

564

Fig. 1: Contaminant concentration versus time at the borehole, following a $M=1$ input for the $\mathrm{n}^{\text {th }}$ flow net. Illustration of the relationship between the concept of vulnerability and the R.T.D. curve: the vulnerability index can be defined as the "area under the curve" higher than the fixed threshold (LR) 
A/ context

- River

- City

+ Boreholes

- Karstic conduits

= Maize

D Protection zone
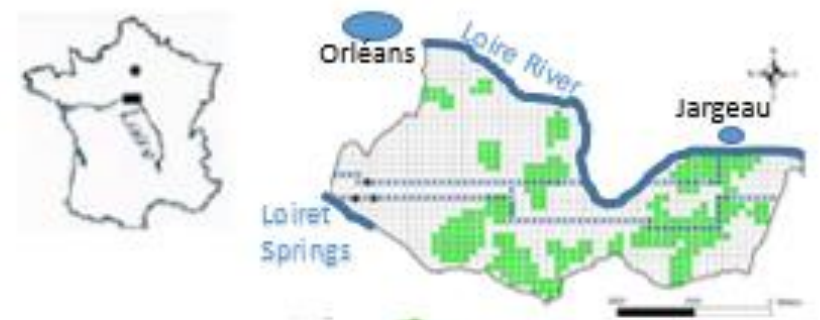

$B$ / Unsaturated zone velocity Water content DI $\mathrm{m} / \mathrm{s} \quad \mathrm{m} / \mathrm{s}$ $\begin{array}{lll}210-7 & 0.33 & 0.4\end{array}$ $\begin{array}{lll}3.510-9 & 0.33 \text { to } 0.4 \quad 0.4\end{array}$ $3.510-9 \quad 0.4$ to $0.5 \quad 0.5$ $10^{-8} \quad 0.5$ to $0.6 \quad 0.5$

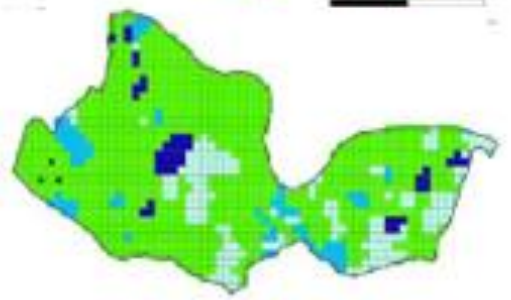

C/ Saturated zone

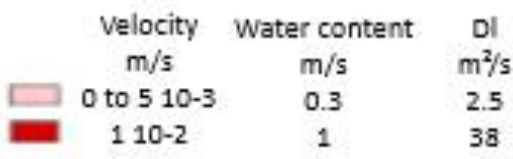

D/ Equivalent residence time

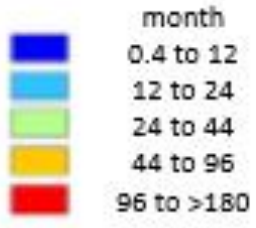

E/ Equivalent Peclet number
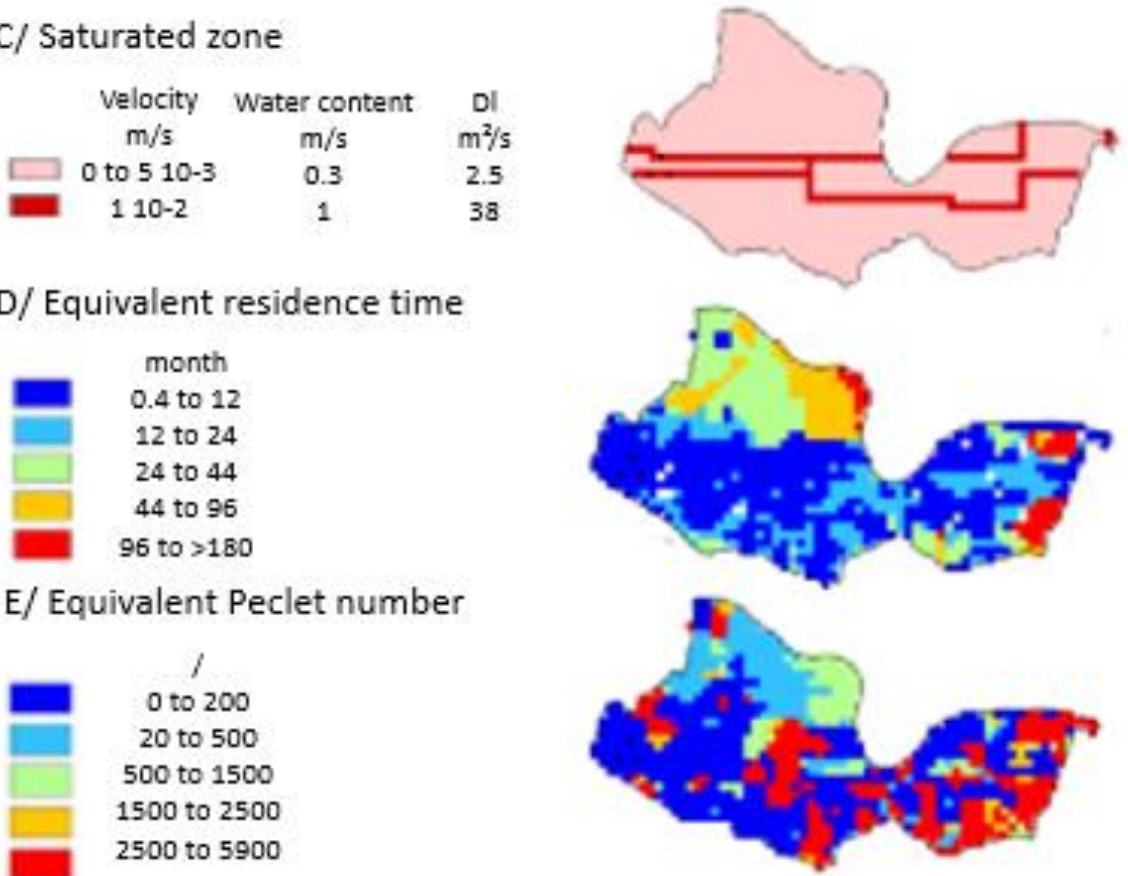

F/ Risk maps
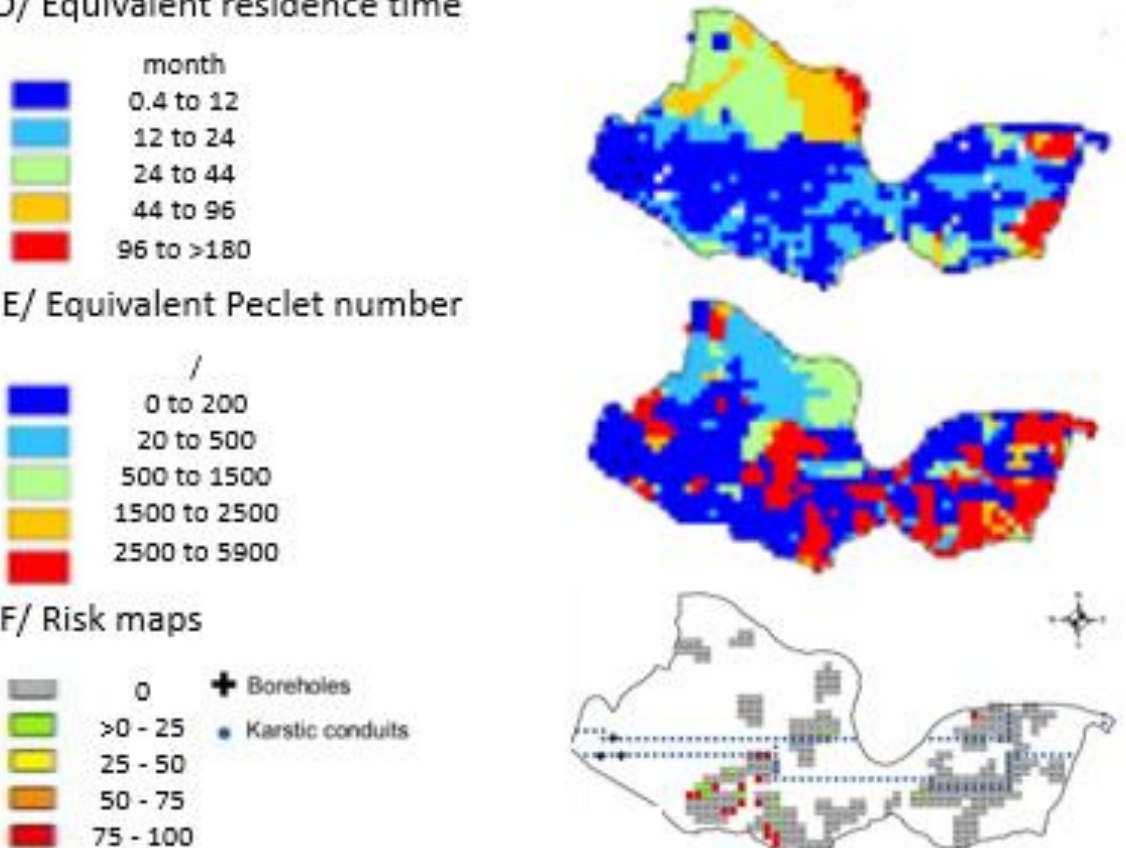

$>0-25$. Karstic conduits

$75-100$

571 Fig. 2: The Val d'Orléans karstic aquifer, A/ grid discretization of the borehole watershed, location of the 2010 maize crop. Spatial distribution of the parameters in B/ the unsaturated and $\mathrm{C} /$ saturated zones. D/ Equivalent residence time and E/ Peclet number, F/ Specific risk map for Atrazine application in the borehole watershed. 


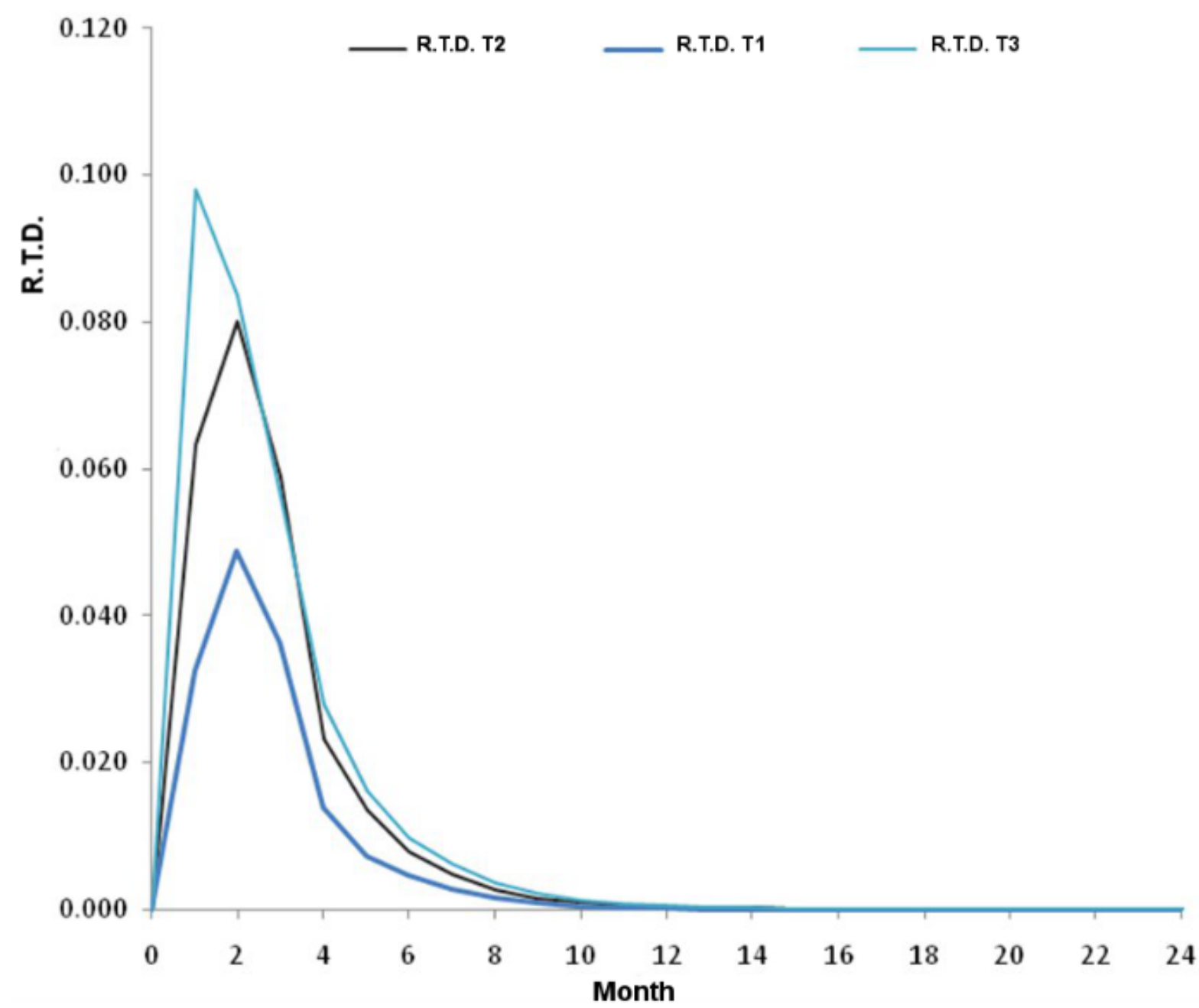

Fig. 3: R.T.D. variability for the Val d'Orléans borehole related to the properties of the unsaturated zone. RTD T1: UZ profile is made of sand (SD), RTD T2 of sand (SD), limestone (LM) and clay (CL), RTD T3 with sand (SD) and 34 karstic point recharges 


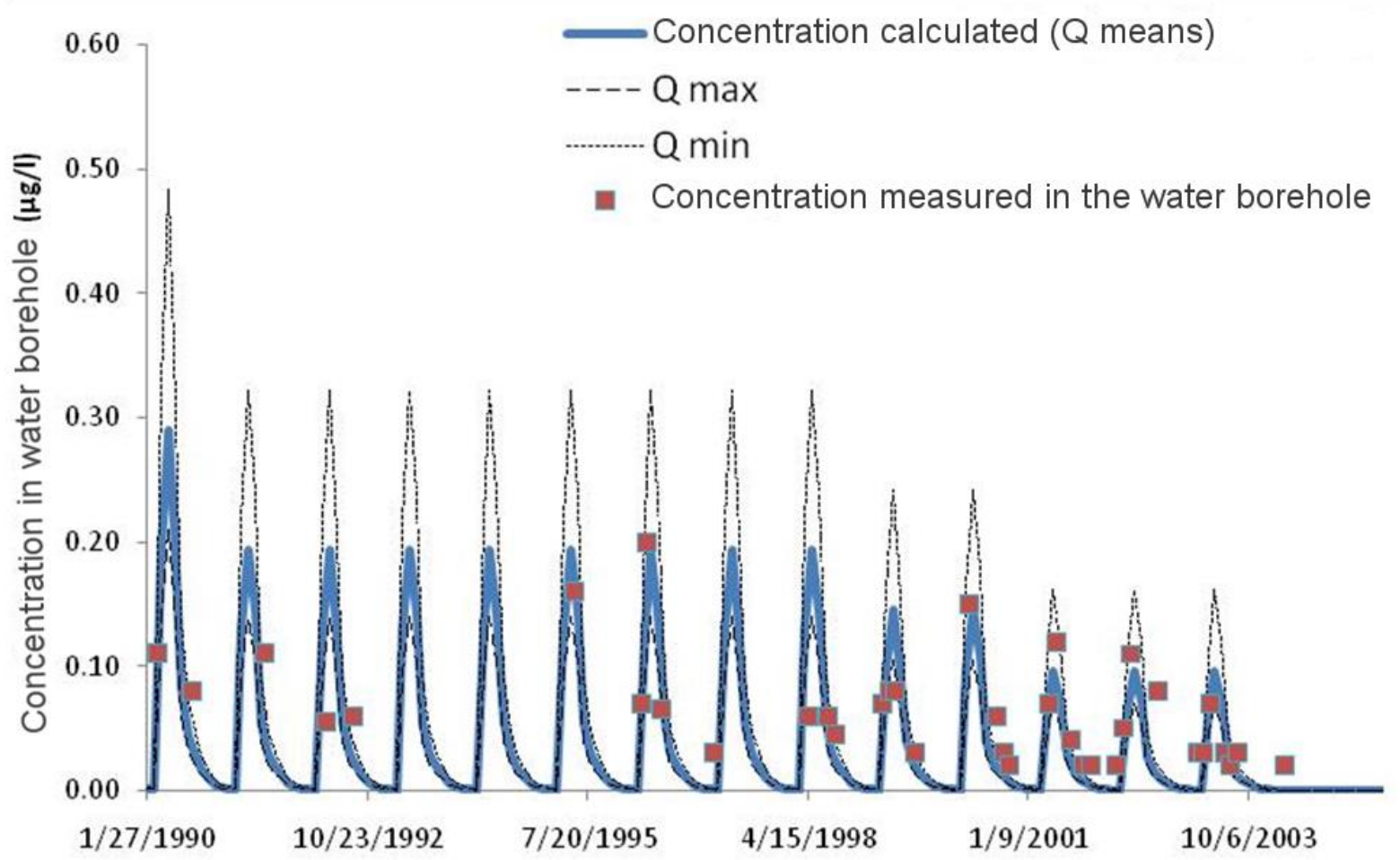

580 Fig. 4: Observed (crosses) and modeled (lines) atrazine concentrations versus time for high, 581 medium and low discharge values at the borehole 